\title{
Review
}

\section{Vitamin D and respiratory infections}

\author{
Fernando de Sá Del Fiol, Silvio Barberato-Filho, Luciane Cruz Lopes, Cristiane de Cássia Bergamaschi \\ Pharmacology Department, University of Sorocaba, Sorocaba, SP, Brazil
}

\begin{abstract}
Vitamin D or 1,25-hydroxyvitamin D $\left(1,25(\mathrm{OH})_{2}\right.$ D) has a well-established role in calcium homeostasis. In recent years, the discovery of vitamin D-metabolizing enzymes and vitamin D receptor (VDR) in the lungs and various cells of the immune system has led to numerous studies conducted to evaluate its role in respiratory functions and, in particular, upper respiratory tract infections (URTIs). A PubMed literature search was done using vitamin D and respiratory infections as key words. Only clinical studies were considered. This study aimed to review recent clinical and epidemiological studies conducted in adults and children, and to evaluate the functional role of vitamin $\mathrm{D}$ in respiratory infections. The evaluated studies show an important immunomodulatory role of vitamin $\mathrm{D}$, which reduces the incidence and risk of URTIs, both in children and in adults. Combating URTIs can be done prophylactically, associating the use of vaccines against Streptococcus pneumoniae with strengthening the immune system through supplementation with vitamin D. These actions can significantly contribute to reducing the number of URTIs, the use of antibiotics, and consequently, the rates of antimicrobial resistance.
\end{abstract}

Key words: vitamin D; respiratory infections; immunomodulatory effect.

J Infect Dev Ctries 2015; 9(4):355-361. doi:10.3855/jidc.5711

(Received 07 August 2014 - Accepted 28 January 2015)

Copyright (C) 2015 de Sá Del Fiol et al. This is an open-access article distributed under the Creative Commons Attribution License, which permits unrestricted use, distribution, and reproduction in any medium, provided the original work is properly cited.

\section{Introduction}

A variety of recent studies have shown that vitamin $\mathrm{D}$ is a regulator of calcium and phosphate homeostasis, and also has numerous extra-skeletal effects. These include effects on the cardiovascular system, central nervous system, endocrine system, and immune system, modulating the innate and adaptive system, influencing the production of endogenous antimicrobial peptides, and regulating the inflammatory cascade [1,2].

Other studies suggest that vitamin D deficiency predisposes patients to respiratory tract infections and may play a role in the development and treatment of asthma [3].

Recently, there have been large numbers of publications involving the role of vitamin $\mathrm{D}$ in upper respiratory infections. Published studies are clinical and epidemiological, all of them involving the use of vitamin $\mathrm{D}$ and its activity in respiratory health $[3,9,35,36,44-46]$. Thus, this study aimed to review recent clinical and epidemiological studies conducted in adults and children, to evaluate the functional role of vitamin $\mathrm{D}$ in respiratory infections.

\section{Source and homeostasis}

The 1,25-dihydroxyvitamin $\mathrm{D}_{3}\left(1,25(\mathrm{OH})_{2} \mathrm{D}_{3}\right)$ is the biologically active form of vitamin D. It is a pleiotropic hormone, regulating calcium and bone homeostasis due to its modulation of $\mathrm{Ca}^{2+}$ ion absorption in the intestine [4]. It also regulates several genes, including those associated with the proliferation, differentiation, and apoptosis of cells [5].

The precursors of vitamin $D$ are vitamins $D_{3}$ (cholecalciferol) and $\mathrm{D}_{2}$ (ergocalciferol) [6]. Vitamin $\mathrm{D}_{3}$ is formed by exposure to solar ultraviolet $\mathrm{B}$ (UVB) rays from its precursor, 7-dehydrocholesterol, present in the skin. It may also be consumed in the diet, particularly in fish fat [7-9].

Both precursor forms, whether synthesized in the skin or obtained through the diet, are hydroxylated in liver by the cytochrome P-450 to 25-hydroxyvitamin $\mathrm{D}(25(\mathrm{OH}) \mathrm{D})$, its detectable and circulating form [8]. The $25(\mathrm{OH}) \mathrm{D}$ released by the liver is not the biologically active form of vitamin $\mathrm{D}$, as that still needs a kidney hydroxylation to become an active compound. Action by the kidney turns $25(\mathrm{OH}) \mathrm{D}$ to 1,25 dihydroxyvitamin $\mathrm{D}\left(1,25(\mathrm{OH})_{2}\right.$ D) or calcitriol, the active form of vitamin $\mathrm{D}$ [6].

Vitamin D $\left(1,25(\mathrm{OH})_{2}\right.$ D) thus synthesized may act directly on the receptor of vitamin D (VDR) [7] 
that is not only present in bones and intestines, but can also be found in bone marrow, brain, pancreas, prostate, and especially in tumor cells and immune cells, suggesting a much broader range of vitamin activity than simply calcium homeostasis $[4,10]$.

\section{Adequate levels}

Around $20 \mathrm{ng} / \mathrm{mL}$ of $25(\mathrm{OH}) \mathrm{D}$ in plasma [11] is considered adequate, and the risk of toxicity occurs when plasma concentrations reach $100 \mathrm{ng} / \mathrm{mL}$ [12]. The plasma concentration of $25(\mathrm{OH}) \mathrm{D}$ is strongly affected by seasonality, since the incidence of sun exposure varies greatly during all four seasons, interfering in a straightforward way in the concentration of vitamin $\mathrm{D}[9,13,14]$. In a study that assessed the plasma concentration of $25(\mathrm{OH}) \mathrm{D}$ in British adults, it was found that in summer, concentrations were double those observed in winter [9]. Another important factor relates to the latitude of the location. Chilean children living in Coyhaique (45 degrees south of the Earth's equatorial plane) had severe degrees of vitamin deficiency due to the small amounts daily solar exposure in the region [15].

Hypervitaminosis D can occur at levels three times greater than normal range, or $100 \mathrm{ng} / \mathrm{mL}$. People working or living in very sunny locations, such as lifeguards, can reach concentrations higher than this without showing effects of hypervitaminosis, manifested by hypercalcemia and renal stone formation [12].

On the other hand, deficiency occurs in individuals without appropriate diet or with low sun exposure. The deficiency is characterized by levels of $25(\mathrm{OH}) \mathrm{D}$ lower than $20 \mathrm{ng} / \mathrm{mL}[5,16,17]$. Another cause of deficiency is age related, due to the decrease of the 7 - dehydrocholesterol precursor in the skin. The difficulties of locomotion in the elderly, with a consequent decrease in sun exposure, also affect the levels of vitamin D [18-20].

Another factor related to decreased levels of vitamin $\mathrm{D}$ relates to skin color. In people with darker skin, melanin acts as a natural sunscreen, competing for UVB rays with 7-dehydrocholesterol and decreasing the formation of vitamin D [6,12]. People with darker skin need up to six times more sun exposure to produce the same amount of vitamin D that lighter-skinned individuals do [21,22].

Use of sunscreens has also been associated with decreased vitamin D production [23,24]. Some studies show that factor 8 sunscreens reduce vitamin production by $95 \%$, reaching $99 \%$ for protection factors above $15[25,26]$.

\section{Supplementation}

The recommended daily intake has been the focus of numerous discussions [27-31]. Recently, in 2011, the Institute of Medicine (IOM), by publishing dietary reference intakes for calcium and vitamin $\mathrm{D}$, suggested a small increase in the recommended daily dose of vitamin. Table 1 shows the dietary reference intakes (DRI) for vitamin D for all life stage groups.

The tolerable upper intake level for children 0-6 months is $1,000 \mathrm{IU}(25 \mu \mathrm{g})$; for children 6-12 months, it is $1,500 \mathrm{IU}(38 \mu \mathrm{g})$; for children $1-3$ years, it is $2,500 \mathrm{IU}(63 \mu \mathrm{g})$; and for children $4-8$ years, it is $3,000 \mathrm{IU}(75 \mu \mathrm{g})$. From age nine to adulthood, the tolerable upper intake level was established to be $4,000 \mathrm{IU}(100 \mu \mathrm{g})[11]$.

Table1. Vitamin D dietary reference intakes (DRIs) for adequacy (amount/day)

\begin{tabular}{lcc}
\hline Life Stage Group & AI & RDA \\
\hline Infants & $400 \mathrm{IU}(10 \mu \mathrm{g})$ & - \\
0 to 12 months & - & $600 \mathrm{IU}(15 \mu \mathrm{g})$ \\
Children & - & $600 \mathrm{IU}(15 \mu \mathrm{g})$ \\
$1-8$ years & - & $800 \mathrm{IU}(20 \mu \mathrm{g})$ \\
Adults (males and females) & - & $600 \mathrm{IU}(15 \mu \mathrm{g})$ \\
$9-70$ years & - & $600 \mathrm{IU}(15 \mu \mathrm{g})$ \\
$>70$ years & - & \\
Pregnancy & -50 years & \\
14-5actation & & \\
$14-50$ years & & \\
\hline AI
\end{tabular}

$\mathrm{AI}=$ adequate intake; $\mathrm{IU}$ = international unit; RDA = recommended dietary allowance. Adapted from IOM [11] 


\section{Activity of vitamin D in URTIs}

The role of vitamin $\mathrm{D}$ in modulating calcium homeostasis has been fully discussed and established, and its action as an immunomodulator has been the subject of several publications that have confirmed its action on the immune system, especially in upper respiratory infections [4,32-36]. The recent discovery of the presence of vitamin D receptors (VDR) in nearly every tissue, especially in cells of the immune system and their ability to metabolize its active form, suggests a strong involvement of vitamin $\mathrm{D}$ in the immune system [37].

Recent studies have shown the direct role of vitamin $D$ in several immune cells such as dendritic cells, B lymphocytes, T lymphocytes, and natural killer (NK) cells $[38,39]$. The production of peptides with antimicrobial activity by macrophages and even beta-defensins by endothelial cells is mediated and stimulated by vitamin D, which shows vitamin D's activity as a mediator of the immune response [40,41].

Cathelicidin is a peptide that has antimicrobial activity against bacteria and viruses. In the presence of viral infections, lung epithelial cells convert inactive vitamin $\mathrm{D}$ into its active form so that it stimulates production of this antimicrobial peptide, helping to fight infection [2]. Animal studies showed a potent effect of cathelicidin in combating influenza A. The authors suggest that the antiviral activity should be controlled by a cathelicidin-mediated immunomodulator [42].

Vitamin D appears to combat infection via multiple mechanisms. It has a direct influence on the production of cathelicidin, which may lead to increased susceptibility to viruses and bacteria, and it influences cytokine profiles during infection via the innate and adaptive immune system [2].

Ginde et al. [3] conducted one of the largest studies of vitamin D in humans. Serum concentrations of vitamin D were assessed in 18,883 volunteers 12 years of age and older. The study correlated the concentration of vitamin $\mathrm{D}$ with the appearance of upper respiratory infections. The study concluded that serum concentrations of the vitamin were inversely related to the occurrence of these infections. The correlation was even stronger in patients with a respiratory disease (asthma and chronic obstructive pulmonary disease [COPD]). The study concluded that supplementation with vitamin D may reduce the incidence of URTIs and also reduce the severity of respiratory tract diseases [3].

Bergman et al. (2013) published a meta-analysis of 11 placebo-controlled studies and included a total of
5,660 patients. This meta-analysis assessed supplements of vitamin D versus placebos and the incidence of URTIs. After the evaluation of 11 randomized controlled trials, the meta-analysis concluded that the use of vitamin $\mathrm{D}$ may be effective in preventing respiratory diseases [35].

A study published in 2013 evaluated a possible correlation between serum 25-hydroxyvitamin D $(25(\mathrm{OH}) \mathrm{D})$ concentrations before admission and risk of hospital-acquired bloodstream infection (HABSI). The retrospective cohort study of 2,135 adult patients evaluated vitamin serum concentrations and correlated them with the emergence of HABSI. Patients who showed prehospital vitamin concentrations of less than $10 \mathrm{ng} / \mathrm{mL}$ were significantly correlated with increased odds of developing HABSI [43].

A meta-analysis published by Charan et al. (2012) evaluated five clinical trials. The outcome events were URTIs in the vitamin D group and the placebo group. The meta-analysis determined that the incidence of URTIs was significantly lower in the groups treated with vitamin D compared to the control groups [44].

A study published in 2011 evaluated the plasma concentration of 11,971 British adults, and correlated it with lung function assessed by spirometry and by episodes of URTIs. The results showed the expected seasonal variation of serum vitamin $\mathrm{D}$ concentration and an inverse relationship with the number of diagnoses of URTIs. There was also strong direct correlation between serum concentrations of vitamin D with lung function as measured by forced expiratory volume (FEV) and forced vital capacity (FVC). The study findings suggest that adequate intakes of vitamin D may have an important role in the appearance of URTIs [9].

In a prospective cohort study published in 2010, the authors evaluated, monthly, the serum concentration of vitamin D in 198 adults, correlating it with the appearance of URTIs. These findings show that concentrations of $38 \mathrm{ng} / \mathrm{mL}$ or more of vitamin $\mathrm{D}$ were associated with a twofold reduction $(p<0.0001)$ in the possibility of the appearance of URTIs. The number of days ill was also reduced in patients with adequate levels of vitamin D [36].

In 2010, a study evaluated the presence of polymerase chain reaction (PCR)-confirmed influenza $A$ in 334 children ranging from 6 to 15 years of age. The children were divided into a treated group $(1,200$ IU/day of vitamin D) and a placebo group. The group treated with vitamin D showed an incidence of $10.8 \%$ influenza $\mathrm{A}$, while in the placebo group, influenza reached $18.6 \%$ of children (relative risk [RR] $0.58, \mathrm{p}=$ 
0.04). The authors suggest that use of vitamin $\mathrm{D}$ in these children during the winter months may reduce the incidence of influenza A [45].

The activity of vitamin $\mathrm{D}$ on lung function was assessed by Choi et al. (2013), who determined the serum concentrations of vitamin $\mathrm{D}$ in more than 10,000 adults in Korea and correlated these with lung function (forced expiratory volume in 1 second [FEV1]). The authors found a positive correlation between the concentration of the vitamin and lung function. This correlation was more evident in patients with tuberculosis [46].

The observations linking vitamin D and innate immune response to infection suggest a possible link between vitamin $\mathrm{D}$ status and susceptibility to tuberculosis [47]. Before the etiologic cause of tuberculosis was determined, cod liver oil and sun exposure were commonly used to treat patients with tuberculosis [48]. Vitamin D levels lower than 30 $\mathrm{ng} / \mathrm{mL}$ have been associated with a higher incidence of tuberculosis [49-51].

Several recent studies have suggested that there is a direct relationship between the concentration of vitamin $\mathrm{D}$ and clinical improvement in patients with tuberculosis [52-56]. A systematic review and metaanalysis in 2008 selected 151 articles published between 1980 and 2006. The meta-analysis concluded that low vitamin D levels were associated with a high risk of active tuberculosis [49].

The association between sun exposure, the concentration of vitamin D, and the clinical improvement of patients with tuberculosis is well established. Future studies should seek detailed information about the mechanism of action and the best dose to be used in tuberculosis treatment.

In a study on other cases of lung diseases such as bronchiectasis, 402 patients with the disease were evaluated for serum levels of vitamin D. The results showed that patients with vitamin deficiencies had higher sputum levels of inflammatory markers and demonstrated a more rapid decline in lung function over three years of follow-ups [57].

The relationship between the umbilical cord blood concentration of vitamin $\mathrm{D}$ in neonates and the presence of respiratory syncytial virus (RSV), the most important pathogen causing lower respiratory tract infection (LRTI) in infants, was evaluated in 146 newborns by Belderbos et al. in 2011. The study showed that low levels of vitamin D in healthy neonates were associated with increased risk of RSVLRTI in the first year of life. The authors suggest that supplementation of vitamin $\mathrm{D}$ in pregnant women could be an important strategy for the prevention of RSV-LRTI during infancy [58].

Another recently published prospective study assessed vitamin D supplementation in milk for children in Mongolia. The double-blind study compared a control group $(n=104)$ with a group that received milk fortified with $300 \mathrm{IU}$ of vitamin $\mathrm{D}_{3}(\mathrm{n}=$ 143). The number of respiratory infections was evaluated in both groups. The study concluded that supplementation of only 300 IU per day in Mongolian children was associated with a significant reduction in parent-reported URTIs [59].

There are also studies that have evaluated the relationship between the concentration of vitamin D and tonsillopharyngitis. Yildiz et al. compared the serum concentration of the vitamin in groups of healthy children and children with recurrent tonsillopharyngitis. In the group of children with tonsillopharyngitis, about $4.7 \%$ of the children had vitamin D levels below $50 \mathrm{nmol} / \mathrm{L}$. No child presented levels below this value in the group of healthy children [60].

Other respiratory infections have been studied for the action of vitamin D. A study published in 2013 evaluated the association between serum concentration of vitamin D and the appearance of infections in 475 school-age children (mean $8.9 \pm 1.6$ years) in Bogotá, Colombia. Children were assessed for a year and their conditions were controlled. At the end of one year, the authors concluded that vitamin D deficiency was associated with increased rates of earache and discharge with fever [61].

\section{Conclusions}

Over the past 70 years, antibiotics have served us very well, dramatically reducing the indicators of global mortality and morbidity [62]. Evolution and adaptation of microorganisms, possible through reactive oxygen species $[63,64]$, forced by the selective pressure caused by the indiscriminate use of antibiotics, has led to a significant decrease in the effectiveness and activity of these drugs through the phenomenon of antimicrobial resistance [65].

The adopted model in the man-microorganism relationship in the last 70 years, proposing to kill bacteria to stop infections, has shown to be flawed, and its time is running out; for that reason, it is essential that we find alternatives to the use of antibiotics. Vaccines have been shown to be extremely effective in making the individual less susceptible to bacterial infections; as a consequence, in countries with greater use of antibiotics, vaccination has resulted 
in decreased antibiotic consumption and a consequent reduction in the indicators of antimicrobial resistance [66].

Recently published studies show that supplementation with vitamin $\mathrm{D}$ in children seems to be a strong ally in fighting the onset of respiratory infections. The combination of vaccines and vitamin D supplementation can significantly reduce the appearance of URTIs and the use of antibiotics, with a consequent decrease of global indicators of bacterial resistance.

The large number of recently published studies and the great variety of actions attributed to vitamin D should show the scientific community that we still know very little about its action. Additional studies should be conducted in order to elucidate its role in human health.

\section{References}

1. Grober U, Spitz J, Reichrath J, Kisters K, Holick MF (2013) Vitamin D: Update 2013: From rickets prophylaxis to general preventive healthcare. Dermatoendocrinol 5: 331-347.

2. Gunville CF, Mourani PM, Ginde AA (2013) The role of vitamin $\mathrm{D}$ in prevention and treatment of infection. Inflamm Allergy Drug Targets 12: 239-245.

3. Ginde AA, Mansbach JM, Camargo CA Jr (2009) Association between serum 25-hydroxyvitamin $\mathrm{D}$ level and upper respiratory tract infection in the Third National Health and Nutrition Examination Survey. Arch Intern Med 169: 384390.

4. Prietl B, Treiber G, Pieber TR, Amrein K (2013) Vitamin d and immune function. Nutrients 5: 2502-21.

5. Holick MF (2007) Vitamin D deficiency. N Engl J Med 357:266-81.

6. Zhang R, Naughton DP (2010) Vitamin D in health and disease: current perspectives. Nutr J 9: 65 .

7. Kulie T, Groff A, Redmer J, Hounshell J, Schrager S (2009) Vitamin D: an evidence-based review. J Am Board Fam Med 22: 698-706.

8. Hughes DA, Norton R (2009) Vitamin D and respiratory health. Clin Exp Immunol 158: 20-25.

9. Berry DJ, Hesketh K, Power C, Hypponen E (2011) Vitamin $\mathrm{D}$ status has a linear association with seasonal infections and lung function in British adults. Br J Nutr 106: 1433-1440.

10. Aranow C (2011) Vitamin D and the immune system. J Investig Med 59:881-6.

11. 11. Holick MF, Chen TC (2008) Vitamin D deficiency: a worldwide problem with health consequences. Am J Clin Nutr 87:1080s-6s.

12. Walker VP, Modlin RL (2009) The vitamin D connection to pediatric infections and immune function. Pediatr Res 65: 106R-13R.

13. Andersen R, Brot C, Jakobsen J, Mejborn H, Molgaard C, Skovgaard LT, Trolle E, Tetens I, Ovesen L (2013) Seasonal changes in vitamin D status among Danish adolescent girls and elderly women: the influence of sun exposure and vitamin D intake. Eur J Clin Nutr 67: 270-274.

14. Diffey BL (2010) Modelling the seasonal variation of vitamin D due to sun exposure. Br J Dermatol 162: 1342-1348.

15. Le Roy C, Reyes M, Gonzalez JM, Perez-Bravo F, CastilloDuran C (2013) [Vitamin D nutrition in Chilean pre-school children living in extreme latitudes]. Rev Med Chil 141: 435441.

16. Lips P, Hosking D, Lippuner K, Norquist JM, Wehren L, Maalouf G, Ragi-Eis S, Chandler J (2006) The prevalence of vitamin $\mathrm{D}$ inadequacy amongst women with osteoporosis: an international epidemiological investigation. J Intern Med 260: 245-254.

17. Yu A, Kim J, Kwon O, Oh SY, Kim J, Yang YJ (2013) The association between serum 25-hydroxyvitamin $d$ concentration and consumption frequencies of vitamin $\mathrm{d}$ food sources in korean adolescents. Clin Nutr Res 2: 107-114.

18. Hirani V, Cumming RG, Blyth FM, Naganathan V, Le Couteur DG, Handelsman DJ, Waite LM, Seibel MJ (2013) Vitamin D Status among Older Community Dwelling Men Living in a Sunny Country and Associations with Lifestyle Factors: The Concord Health and Ageing in Men Project, Sydney, Australia. J Nutr Health Aging 17: 587-593.

19. Troesch B, Eggersdorfer M, Weber P (2012) The role of vitamins in aging societies. Int J Vitam Nutr Res 82: 355-359. 
20. Hilger J, Friedel A, Herr R, Rausch T, Roos F, Wahl DA, Pierroz DD, Weber P, Hoffmann K (2013) A systematic review of vitamin $\mathrm{D}$ status in populations worldwide. $\mathrm{Br} \mathrm{J}$ Nutr: 1-23.

21. Clemens TL, Adams JS, Henderson SL, Holick MF (1982) Increased skin pigment reduces the capacity of skin to synthesise vitamin D3. Lancet 1: 74-76.

22. Chen TC, Chimeh F, Lu Z, Mathieu J, Person KS, Zhang A, Kohn N, Martinello S, Berkowitz R, Holick MF (2007) Factors that influence the cutaneous synthesis and dietary sources of vitamin D. Arch Biochem Biophys 460: 213-217.

23. Tsiaras WG, Weinstock MA (2011) Factors influencing vitamin D status. Acta Derm Venereol 91: 1151-24.

24. Loden M, Beitner H, Gonzalez H, Edstrom DW, Akerstrom U, Austad J, Buraczewska-Norin I, Matsson M, Wulf HC (2011) Sunscreen use: controversies, challenges and regulatory aspects. Br J Dermatol 165: 255-262.

25. Matsuoka LY, Ide L, Wortsman J, MacLaughlin JA, Holick MF (1987) Sunscreens suppress cutaneous vitamin D3 synthesis. J Clin Endocrinol Metab 64: 1165-1168.

26. Holick MF (1994) McCollum Award Lecture, 1994: vitamin D--new horizons for the 21st century. Am J Clin Nutr 60: 619-630.

27. Ozkan B, Hatun S, Bereket A (2012) Vitamin D intoxication. Turk J Pediatr 54: 93-98.

28. Anik A, Catli G, Abaci A, Dizdarer C, Bober E (2013) Acute vitamin $\mathrm{D}$ intoxication possibly due to faulty production of a multivitamin preparation. J Clin Res Pediatr Endocrinol 5: 136-139.

29. Benemei S, Gallo E, Giocaliere E, Bartolucci G, MennitiIppolito F, Firenzuoli F, Mugelli A, Vannacci A (2013) It's time for new rules on vitamin D food supplements. Br J Clin Pharmacol 76: 825-856.

30. Bothra M, Jain V (2013) Vitamin d intoxication: too much of a good thing! Indian Pediatr 50: 429-430.

31. Glade MJ (2012) A 21st century evaluation of the safety of oral vitamin D. Nutrition 28: 344-356.

32. Taylor CE, Camargo CA Jr (2011) Impact of micronutrients on respiratory infections. Nutr Rev 69: 259-269.

33. Inamo $Y$, Hasegawa $M$, Saito $K$, Hayashi $R$, Ishikawa $T$, Yoshino Y, Hashimoto K, Fuchigami T (2011) Serum vitamin $\mathrm{D}$ concentrations and associated severity of acute lower respiratory tract infections in Japanese hospitalized children. Pediatr Int 53: 199-201.

34. Battersby AJ, Kampmann B, Burl S (2012) Vitamin D in early childhood and the effect on immunity to Mycobacterium tuberculosis. Clin Dev Immunol 2012: 430972.

35. Bergman P, Lindh AU, Bjorkhem-Bergman L, Lindh JD (2013) Vitamin D and Respiratory Tract Infections: A Systematic Review and Meta-Analysis of Randomized Controlled Trials. PLoS One 8: e65835.

36. Sabetta JR, DePetrillo P, Cipriani RJ, Smardin J, Burns LA, Landry ML (2010) Serum 25-hydroxyvitamin d and the incidence of acute viral respiratory tract infections in healthy adults. PLoS One 5: e11088.

37. Bikle DD (2008) Vitamin D and the immune system: role in protection against bacterial infection. Curr Opin Nephrol Hypertens 17: 348-352.

38. Deluca HF, Cantorna MT (2001) Vitamin D: its role and uses in immunology. Faseb j 15: 2579-2585.

39. van Etten E, Mathieu C (2005) Immunoregulation by 1,25dihydroxyvitamin D3: basic concepts. J Steroid Biochem Mol Biol 97: 93-101.
40. White JH (2010) Vitamin D as an inducer of cathelicidin antimicrobial peptide expression: past, present and future. J Steroid Biochem Mol Biol 121: 234-238.

41. Wang TT, Nestel FP, Bourdeau V, Nagai Y, Wang Q, Liao J, Tavera-Mendoza L, Lin R, Hanrahan JW, Mader S, White JH (2004) Cutting edge: 1,25-dihydroxyvitamin D3 is a direct inducer of antimicrobial peptide gene expression. J Immunol 173: 2909-2912.

42. Barlow PG, Svoboda P, Mackellar A, Nash AA, York IA, Pohl J, Davidson DJ, Donis RO (2011) Antiviral activity and increased host defense against influenza infection elicited by the human cathelicidin LL-37. PLoS One 6: e25333.

43. Quraishi SA, Litonjua AA, Moromizato T, Gibbons FK, Camargo CA Jr, Giovannucci E, Christopher KB (2013) Association between prehospital vitamin $\mathrm{D}$ status and hospital-acquired bloodstream infections. Am J Clin Nutr 98: 952-959.

44. Charan J, Goyal JP, Saxena D, Yadav P (2012) Vitamin D for prevention of respiratory tract infections: A systematic review and meta-analysis. J Pharmacol Pharmacother 3: 300-303.

45. Urashima M, Segawa T, Okazaki M, Kurihara M, Wada Y, Ida H (2010) Randomized trial of vitamin D supplementation to prevent seasonal influenza A in schoolchildren. Am J Clin Nutr 91: 1255-1260.

46. Choi CJ, Seo M, Choi WS, Kim KS, Youn SA, Lindsey T, Choi YJ, Kim CM (2013) Relationship between serum 25hydroxyvitamin D and lung function among Korean adults in Korea National Health and Nutrition Examination Survey (KNHANES), 2008-2010. J Clin Endocrinol Metab 98: 17031710.

47. Chun RF, Adams JS, Hewison M (2011) Immunomodulation by vitamin D: implications for TB. Expert Rev Clin Pharmacol 4: 583-591.

48. Chocano-Bedoya P, Ronnenberg AG (2009) Vitamin D and tuberculosis. Nutr Rev 67: 289-293.

49. Nnoaham KE, Clarke A (2008) Low serum vitamin D levels and tuberculosis: a systematic review and meta-analysis. Int $\mathrm{J}$ Epidemiol 37: 113-119.

50. Martineau AR, Wilkinson RJ, Wilkinson KA, Newton SM, Kampmann B, Hall BM, Packe GE, Davidson RN, Eldridge SM, Maunsell ZJ, Rainbow SJ, Berry JL, Griffiths CJ (2007) A single dose of vitamin $\mathrm{D}$ enhances immunity to mycobacteria. Am J Respir Crit Care Med 176: 208-213.

51. Zhan Y, Jiang L (2015) Status of vitamin D, antimicrobial peptide cathelicidin and $\mathrm{T}$ helper-associated cytokines in patients with diabetes mellitus and pulmonary tuberculosis. Exp Ther Med 9: 11-16.

52. Nielsen NO, Skifte T, Andersson M, Wohlfahrt J, Soborg B, Koch A, Melbye M, Ladefoged K (2010) Both high and low serum vitamin $\mathrm{D}$ concentrations are associated with tuberculosis: a case-control study in Greenland. Br J Nutr 104: 1487-1491.

53. Williams B, Williams AJ, Anderson ST (2008) Vitamin D deficiency and insufficiency in children with tuberculosis. Pediatr Infect Dis J 27: 941-942.

54. Yamshchikov AV, Kurbatova EV, Kumari M, Blumberg HM, Ziegler TR, Ray SM, Tangpricha V (2010) Vitamin D status and antimicrobial peptide cathelicidin (LL-37) concentrations in patients with active pulmonary tuberculosis. Am J Clin Nutr 92: 603-611.

55. Ho-Pham LT, Nguyen ND, Nguyen TT, Nguyen DH, Bui PK, Nguyen VN, Nguyen TV (2010) Association between vitamin 
D insufficiency and tuberculosis in a Vietnamese population. BMC Infect Dis 10: 306.

56. Sato S, Tanino Y, Saito J, Nikaido T, Inokoshi Y, Fukuhara A, Fukuhara N, Wang X, Ishida T, Munakata M (2012) Relationship between 25-hydroxyvitamin D levels and treatment course of pulmonary tuberculosis. Respir Investig 50: $40-45$.

57. Chalmers JD, McHugh BJ, Docherty C, Govan JR, Hill AT (2013) Vitamin-D deficiency is associated with chronic bacterial colonisation and disease severity in bronchiectasis. Thorax 68: 39-47.

58. Belderbos ME, Houben ML, Wilbrink B, Lentjes E, Bloemen EM, Kimpen JL, Rovers M, Bont L (2011) Cord blood vitamin $\mathrm{D}$ deficiency is associated with respiratory syncytial virus bronchiolitis. Pediatrics 127: e1513-1520.

59. Camargo CA, Jr., Ganmaa D, Frazier AL, Kirchberg FF, Stuart JJ, Kleinman K, Sumberzul N, Rich-Edwards JW (2012) Randomized trial of vitamin D supplementation and risk of acute respiratory infection in Mongolia. Pediatrics 130: e561-567.

60. Yildiz I, Unuvar E, Zeybek U, Toptas B, Cacina C, Toprak S, Kilic A, Aydin S (2012) The role of vitamin D in children with recurrent tonsillopharyngitis. Ital J Pediatr 38: 25.

61. Thornton KA, Marin C, Mora-Plazas M, Villamor E (2013) Vitamin D deficiency associated with increased incidence of gastrointestinal and ear infections in school-age children. Pediatr Infect Dis J 32: 585-593.
62. Yoshikawa TT (2002) Antimicrobial resistance and aging: beginning of the end of the antibiotic era? J Am Geriatr Soc 50: S226-229.

63. Liu Y, Liu X, Qu Y, Wang X, Li L, Zhao X (2012) Inhibitors of reactive oxygen species accumulation delay and/or reduce the lethality of several antistaphylococcal agents. Antimicrob Agents Chemother 56: 6048-6050.

64. Mosel M, Li L, Drlica K, Zhao X (2013) Superoxidemediated protection of Escherichia coli from antimicrobials. Antimicrob Agents Chemother 57: 5755-5759.

65. Devasahayam G, Scheld WM, Hoffman PS (2010) Newer antibacterial drugs for a new century. Expert Opin Investig Drugs 19: 215-234.

66. Dagan R, Klugman KP (2008) Impact of conjugate pneumococcal vaccines on antibiotic resistance. Lancet Infect Dis 8: 785-795

\section{Corresponding author}

Dr. Fernando de Sá Del Fiol

Universidade de Sorocaba

Rodovia Raposo Tavares, Km 92,5

CEP: 18023-000, Brasil

Phone: 5515996170589

Fax: 551521017074

Email: fernando.fiol@prof.uniso.br

Conflict of interests: No conflict of interests is declared. 